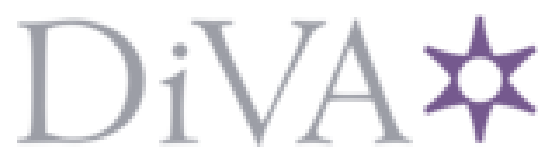

http://www.diva-portal.org

\title{
Postprint
}

This is the accepted version of a paper published in International Journal of Entrepreneurial Behaviour $\&$ Research. This paper has been peer-reviewed but does not include the final publisher proofcorrections or journal pagination.

Citation for the original published paper (version of record):

Brundin, E., Gustafsson, V. (2013)

Entrepreneurs' decision making under different levels of uncertainty: the role of emotions.

International Journal of Entrepreneurial Behaviour \& Research, 19(6): 568-591

http://dx.doi.org/10.1108/IJEBR-07-2012-0074

Access to the published version may require subscription.

N.B. When citing this work, cite the original published paper.

Permanent link to this version:

http://urn.kb.se/resolve?urn=urn:nbn:se:hj:diva-22312 


\title{
Entrepreneurs' Decision-Making under Different Levels of Uncertainty: The Role of Emotions
}

\author{
Ethel Brundin \& Veronika Gustafsson
}

\begin{abstract}
Purpose - This study investigates entrepreneurs' investment decisions under uncertainty in continued investments where we test the role of emotions to continue or discontinue the investment.

Design/methodology/approach - A conjoint analysis is carried out on 101 entrepreneurs' 3,232 investment decisions. The entrepreneurs were provided with a scenario of an investment where the dependent variable was the entrepreneur's propensity to allocate further resources to the described investment. They assessed their willingness to allocate further resources to the investment on a seven-point Likert-type scale. The independent variables in our experiment were the experienced emotions of the entrepreneur each of which was described by the two levels of high and low.

Findings - It was found that self-confidence, challenge, and hope increase the propensity to continue investments as do increased level of uncertainty. Embarrassment and strain do not increase this propensity however high uncertainty decreases the propensity to continue investments. In contrast to the escalation of commitment theory, embarrassment does not make entrepreneurs more prone to invest under uncertainty. Frustration does not yield significant results, which runs contrary to the theory and our hypothesis finds no support.

Originality/value - This study is an experiment where practitioner entrepreneurs participate which increases the ecological validity of the study. Emotions can explain, partly, why entrepreneurs persist with some underperforming projects, but not others. Uncertainty is a powerful moderating variable in the decision-making process. The results enhance existing knowledge about the emotive side of entrepreneurs' propensity to make investment decisions under uncertainty. The results also supplement and refine existing theories on selfjustification.
\end{abstract}

Keywords - Emotions, Entrepreneurs, Decision making, Uncertainty, Small to medium sized Enterprises

Paper type - Research paper 


\section{Entrepreneurs' Decision Making under Different Levels of Uncertainty: The Role of Emotions}

\section{Introduction}

Why is it that entrepreneurs may decide to keep investing financial resources into a project which might be a failure and therefore nothing but a case of throwing good money after bad? According to the theories of rational choice, entrepreneurs should terminate failing investments as soon as possible; still scholars have noticed that individuals often persist with and continue to commit resources to a failing course of action (Staw, 1981).

The theoretical area of decision-making is widely explored from numerous cognitive perspectives, e.g. theories of rational choice, which also identify and investigate numerous decision biases (Tversky and Kahneman, 1974). One of the most common decision biases is the inability to discontinue investment in a failing project. Previous studies have concluded that reasons such as sunk costs and extrinsic motivation (Detienne et al., 2008), exit costs (Karakaya, 2000), intrinsic motivation (Gimeno et al., 1997), overconfidence (McCarthy et al., 1933), previous success (Levinthal, 1991), and social norms (McGrath, 1999) may influence the likelihood that entrepreneurs persist with their commitment to underperforming enterprises.

While the literature on decision-making has substantially developed over the last 30 years in both laboratory settings (e.g. Garland, 1990; Sabherwal et al., 2003) and real world case studies (Ross and Staw, 1986), until now little attention has been paid to the emotional side of these decisions. We still know little about what role the emotions of the entrepreneurs play when they invest under different levels of uncertainty. Yet, we know that entrepreneurs act with emotions (Cardon et al., 2005). They are not merely rational 'computers' and the fact that emotions matter in entrepreneurial processes is today a well-established argument (Cardon et al., 2005; Author ref.; Markman et al., 2002). Emotions constitute an asset and an additional mechanism that is unexploited and underestimated, leaving more questions to be 
answered than those already addressed (Cardon et al., 2012). Hence we argue that there is reason to pursue an investigation of emotions posing as major cognitive factors for decisionmakers in cases where sunk monetary costs, i.e. resources already used up (Ross and Staw, 1986) are a fact. We hypothesize that this is especially true under different levels of uncertainty, which becomes an important moderator.

Our goal with this study is to investigate the role of entrepreneurs' emotions in their investment decisions under different levels of uncertainty. Emotions are defined in line with Cardon et al.'s (2012) suggestion that entrepreneurial emotion refers “to the affect, emotions, moods, and/or feelings - of individuals or a collective - that are antecedent to, concurrent with, and/or a consequence of the entrepreneurial process, meaning the recognition/creation, evaluation, reformulation, and/or the exploitation of a possible opportunity” (p. 3). We will rely on emotions that have been proven to play a role in entrepreneurial leadership (Author et al., ref.), and in escalation of commitment (Karlsson et al., 2005) namely challenge, embarrassment, frustration, hope, self-confidence, and strain. An entrepreneur is here equal to an owner-manager, that is, a person who has an ownership stake in the firm and is actively involved in the running of the firm. Such a definition also mirrors the fact that ownership and decision making are central to entrepreneurship (Ucbasaran et al., 2008).

In this study, we combine the theoretical fields of cognitive psychology and decision bias research (including escalation of commitment) with the emotion literature. Thus the paper makes a theoretical contribution by providing further insights into the cognitive aspects of emotions by studying how entrepreneurs are affected not only by their emotions but also by the level of uncertainty. This has important practical, as well as theoretical implications, since entrepreneurs usually act in environments characterized by a high level of uncertainty and ambiguity (Sarasvathy, 2001). In doing so, we address "the thinking-feeling-doing connection” (Cardon et al., 2012). 
The next section presents our theory and hypotheses. From there follows a description of our method and the collection of 101 decision-makers’3,232 investment decisions where the dependent variable is the propensity to continue investments in situations characterized by high and low uncertainty levels and where the entrepreneur perceives a set of emotions. A section containing the results, discussion, and implications will conclude the paper.

\section{Emotions and propensity to invest under different levels of uncertainty}

Research has already pointed out that entrepreneurial decision making often departs from the rational economic model (Kahneman and Tversky, 1973) and emotions and cognitive biases are now regarded as important theoretical phenomena in entrepreneurship research (cf. Mitchell et al., 2002). Recent studies have confirmed this assumption and demonstrated that emotions play an important role for entrepreneurs' opportunity evaluation and exploitation, risk perception and commitment to entrepreneurial ventures (Foo, 2011; Welpe et al., 2012). Thus, Hayward et al. (2010) show that confidence is important for decisions of serial entrepreneurship; Welpe et al., (2012) conclude that fear reduces exploitation decisions whereas joy and anger increase such decisions; Hayton and Cholakova (2012) highlight the role of emotions for decision making concerning the pursuit of an idea, hypothesizing that positive affects help entrepreneurs to take in more information, remember it and combine it into novel and creative thinking. Breugst et al. (2012) and Author (ref.) turn to the decision-making power of employees and show in their respective studies how emotions displayed by the entrepreneur make the employees more or less inclined to commit themselves to an entrepreneurial venture or to be entrepreneurial. However, the question of how positive and negative emotions affect decision making, especially under conditions of uncertainty, remains, to a large extent, unresolved. For example, the propensity of a decisionmaker to continue a seemingly unsuccessful investment is a recognized decision bias (Brockner, 1992). 
Studies have revealed that entrepreneurs are prone to numerous decision biases (Baron, 1998; Busenitz and Barney, 1997). An explanation for this decision behavior can be found in the role of entrepreneurial environments, characterized by information overload, high uncertainty or novelty, strong emotions, time pressure, and fatigue (Baron, 1998). Selfjustification theory shows that people in charge of investment decisions have a tendency to justify a failing course rather than interrupt it when they realize the upcoming financial setback (Ross and Staw, 1986). They simply seem to be more motivated to pursue their investments. If the entrepreneur continues to invest, such actions also show persistence and thereby strong leadership (Yukl, 2010). However, self-justification theory only provides a partial explanation of a complex phenomenon, and supplementary theories exist, e.g., prospect theory (Northcraft and Neale, 1986).

Taking all these factors into account, it is reasonable to assume that entrepreneurs can be prone to persist in their investment behavior, and this propensity can be influenced by strong emotions. We aim to investigate an important and frequently occurring property of entrepreneurial decision-making behaviors in real life; it thus becomes imperative to turn to practitioner entrepreneurs in order to fully understand their decision-making practices under different levels of uncertainty. In this study, the owner-managers of SMEs are by definition considered entrepreneurs following a stream of research in the entrepreneurship field, which equates entrepreneurship with running an independent business (Davidsson, 2007).

In this study we test emotions of challenge, hope, self-confidence, embarrassment, frustration, and strain, which have already demonstrated the ability to influence decisionmaking, also in entrepreneurial settings. In Author et al.'s (ref.) study, top managers displayed frustration, self-confidence, and strain as having an impact on entrepreneurial behavior. Further, confidence is in focus of Hayward et al.'s (2010) study where it is defined as an emotionally-laden belief and Podoynitsyna et al. (2012) list challenge and hope as two 
of sixteen relevant emotions in the risk perception of novice and serial entrepreneurs. The specific combination of the emotions in this study was evident in a longitudinal study of over twenty months as the most salient in strategic change processes and therefore deemed relevant for our experiment (Author ref). Most of these emotions fall under the category of so-called cognitive emotions (Michl et al., 2009) and we also rely on Lazarus’(1984; 1991a) argument of the bidirectional relationship between emotion and cognition. In this study we thus refer to both affective and cognitive emotions as defined by Cardon et al. (2012) and we define all of them as emotions.

\section{Emotions and propensity to invest}

Following the lead of Rafaeli and Sutton (1987), and Isen et al. (1987), we divide emotions into positive or negative for the purpose of our study. However, there is a need to be careful when dividing emotions into positive and negative in order to make sure that they are functionally treated the same (Gooty et al. (2009). So, for example, sadness may be positive in a cooperative crisis situation or in a situation with a greater amount of trust, whereas the same emotion may be negative in a competitive crisis situation or a situation characterized with more distrust (van Kleef et al., 2010). Our study is based on approach and avoidance emotions, affecting attitudes and behavior (Lazarus and Yochi Cohen-Charash, 2001) in entrepreneurs' decision whether to continue or discontinue an investment. In our study an emotion is positive when the entrepreneur perceives the situation as favorable and has a good feeling in general and therefore aims higher. Positive emotions also tend to make people more prone to creative thinking (Barbalet, 1996). In an underperforming situation, this would imply that the decision-maker appreciates the situation as surmountable and believes that the outcome is positive. Challenge, hope, and self-confidence are here labeled and tested as positive and they all indicate action since they engender the feeling that it will be right thing to do (cf. Groves et al., 2011). An emotion is negative when the individual is not certain 
about his or her own capacity and is blurred or blocked by the emotion mentally; the emotion makes him or her avert to uncertainty (Dequech, 2000). Embarrassment, frustration, and strain are labeled and tested as negative emotions in this study. In Shaver et al. (1987), embarrassment and strain are grouped within the same main category of sadness, whereas frustration is placed within anger, all of these emotions supposedly leading to withdrawal or counterproductive work behavior (cf. Gooty et al., 2009). Further, in a study undertaken by Basch and Fisher (2000), frustration is grouped together with sadness and embarrassment and in a previous study concerning entrepreneurs' emotional displays (Author, 2008), frustration was grouped with strain as a negative emotion in a conjoint experiment.

\section{Positive Emotions}

Self-confidence is an emotion that refers to a belief in oneself. The concept of 'self' stands for a reflection of what an individual thinks he or she is capable of (Pierce et al., 1989). Confidence involves action and agency (Barbalet, 1996); self-confidence therefore involves self-projection that spurs the individual to action. According to Barbalet (1996), it "brings the future into the present by providing a sense of certainty to what is essentially unknowable so that assured action with regard to it may be engaged” (p. 81). For entrepreneurs, self-confidence makes them goal directed and keen to pursue highly-esteemed investments (cf. Snyder, 2002), as well as willing to face uncertainty (Dequech, 2000). When entrepreneurs feel self-confidence with respect to an underperforming investment, they believe that they are capable of turning it around, and achieving the desired goals.

Hope involves goal achievement, agency, and pathways to one’s goals (Henry, 2004; Snyder, 1995). It is "an overall perception that goals can be met” (Henry, 2004, p. 385). In a similar way, more social in character, Averill et al. (1990) argue that hope is governed by a goal that is under control to a certain degree and is in between probability of attainment and in accordance with social acceptance. Entrepreneurs are thus positive about the probability of 
reaching the goal in an underperforming situation, and the ways to reach it, regardless of the setback of having lost money initially. Higher levels of hope will lead entrepreneurs to perceive more control over the investment (Averill et al., 1990) and motivate them to persist (Anderson, 2003).

Challenge is an action-motivating emotion that is energizing, where the individual perceives possible gains focusing on opportunities for success, personal growth, advancement, and social rewards (Henry, 2004; Lazarus, 1991b). Challenge indicates confidence to overcome hardship by making considerable amounts of effort (Skinner and Brewer, 2002). Author (ref.) empirically found challenge to be an emotion that matters for strategic leaders in order to face exciting or difficult tasks. For entrepreneurs, challenge thus involves readiness to act and to find new solutions in order to achieve a positive investment outcome. Entrepreneurs who are challenged by turning a failing investment around feel energized by their efforts - and are willing to put in high levels of effort - to avoid failure. In sum, it appears that entrepreneurs' feelings of self-confidence, hope, and challenge may increase the propensity to continue with investment in a seemingly failing project.

Thus, the following hypothesis was formulated:

H1: The stronger the positive emotions ([a] self-confidence, [b] hope, [c] challenge) entrepreneurs feel in relation to a project, the higher is their propensity to continue investing in this project.

\section{Negative Emotions}

Frustration stems from the so-called basic emotion of anger (Ekman, 1992) and occurs when "an instigated goal-response (or predicted behavioral sequence) is interrupted or interdicted” (Fox and Spector, 1999, p. 916). Researchers consider frustration a dysfunctional emotion, often leading to stress (Hutri and Lindeman, 2002), and this has a negative influence on performance (McColl-Kennedy and Anderson, 2002). For entrepreneurs, this implies that 
their frustration about an underperforming investment makes them prone to make a decision which is at the time the easiest 'way out'. The frustration makes them avoid the situation and they therefore cut off an investment in order to get rid of the obstacles rather than face the possibility of more hindrances. Entrepreneurs feeling frustrated with respect to a failing investment perceive various obstacles blocking the advancement of that investment.

Embarrassment is a preachment of etiquette (Darwin, 1872/1965) and since the prevailing discourse for entrepreneurs is to be successful, a failure is very likely to cause embarrassment. Embarrassment is the result of the threat a person feels with regard to his or her social identity and the negative feeling relating to a faux pas (Goffman, 1956). In a decision-making process, embarrassment probably has cognitive connotations where the decision-maker relates a possible failure to uneasiness in terms of losing self-esteem, concern for others' evaluation, or lack of scripts for how to act. Embarrassment for entrepreneurs in decision-making when it comes to failing investments is an awkward feeling (Miller and Leary, 1992) and implies that they anticipate other people's negative evaluation and they do not wish to lay bare their incompetence and face a possibly greater loss. Therefore, they cut off an investment instead of pursuing a lost cause. To the extent that the entrepreneurs believe that the investment will fail, they may feel embarrassment associated with numerous decisions to persist and the increasing costs of the failure when it eventually occurs. Thus, embarrassment becomes an avoidance emotion and makes entrepreneurs who feel embarrassment less likely to persist and invest further resources in a failing investment.

The underpinning meaning of strain is embedded in emotions such as agony, suffering, anguish, despair, hopelessness, and the like (Shaver et al., 1987). Strain is an emotion that has a negative impact on a person's well-being, leading to tension, fatigue, exhaustion, and in some cases mental illness (Karasek, 1979). Strain encompasses appraisal as well as coping (Lazarus, 1991b), i.e., strain is how the individual interprets the situation 
and how s/he responds to it. Author (ref.) found that strain may make strategic leaders vulnerable and less impassioned about their strategic goal. Strain arises when what the entrepreneurs appraise severely thwarts or jeopardizes their goals and intentions. Strain is directed towards the situation of decision making and is therefore focused on this specific situation (cf. Parkinson et al., 1996). The decision-maker wants to get rid of the burden that the investment represents and therefore cuts off the investment. Entrepreneurs who feel strain are therefore more likely to terminate a failing investment.

Taken together, we assume that entrepreneurs who feel frustration, embarrassment, and strain will not be prone to invest further resources into a failing project, and hence we hypothesize as follows:

H2: The stronger the negative emotions ([d] frustration, [e] embarrassment, [f] strain) entrepreneurs feel towards a project, the lower is their propensity to continue investing in the project.

\section{Uncertainty in investment decisions}

While we may assume that certain emotions might encourage and other emotions might discourage entrepreneurs in terms of persisting with a failing project, the effect of emotional outcomes on entrepreneurial persistence is unlikely to be equal in all decision situations. Although many of these factors (e.g., sunk costs, motivation, and social context) may interfere with the entrepreneurs' considerations of emotions in their decisions to persist, we focus on the entrepreneurs' willingness to continue to invest in an underperforming project. A considerable body of research has emphasized that dealing with uncertainty is central for entrepreneurial decision making (Herbert and Link, 1988; McMullen and Shepherd, 2006).

Entrepreneurs will face higher levels of investment uncertainty when they have little information and knowledge about possible investment outcomes (cf. McMullen and 
Shepherd, 2006). In these situations, the cognitive role of emotions associated with persistence appears particularly strong. First, according to the consequentialist perspective of behavioral decision making, individuals cognitively evaluate and compare potential decision outcomes and the probabilities of these outcomes, and then make their decisions based on that evaluation (Lucey and Dowling, 2005). With more information on potential decision outcomes and thus more decision cues available, however, decision-makers need to focus their limited attention on a few of those cues (Gifford, 1997; Kahneman et al., 1992). That is, when investment uncertainty is high and little information on investment outcomes is available, entrepreneurs can focus more of their attention on the cognitive evaluation of emotions. In this latter case, emotions will have a stronger impact on the entrepreneurs' decisions.

Second, the 'risk-as-feelings' perspective on decision making suggests that the cognitive evaluations of decision outcomes "have affective consequences, and feeling states also exert a reciprocal influence on cognitive evaluations” (Loewenstein et al., 2001, p. 270). For example, when entrepreneurs feel self-confidence in an underperforming project, they may experience feelings of self-confidence at the time of the evaluation of the decision situation. This enhanced belief in their abilities and competencies (Pierce et al., 1989) increases their willingness to face uncertainties associated with the outcomes of the investment (Dequech, 2000). In contrast, when entrepreneurs feel that persistence will be associated with high levels of strain, they may experience feelings of strain during their evaluations of investment outcomes. Since strain is often manifested in feelings of anxiety (Karasek, 1979), these entrepreneurs appear less willing to face the outcome uncertainties of the investment. It therefore appears that positive emotions associated with persistence enhance, while negative emotions diminish the entrepreneurs' willingness to continue. In contrast, when the future trajectory of the investment is less uncertain and potential outcomes 
and outcome probabilities are known, the effects that the entrepreneurs' emotions have on their willingness to bear uncertainties become less prevalent.

Bearing in mind the potential moderating role of uncertainty, we are able to derive the following hypotheses:

H3: Uncertainty moderates the relationship between the positive emotions ([a] selfconfidence, [b] hope, [c] challenge) and the propensity to invest in such a way that the propensity to invest increases when the uncertainty associated with the project is high; the propensity to invest under the same emotions decreases when the uncertainty is low.

H4: Uncertainty moderates the relationship between the negative emotions ([d] frustration, [e] embarrassment, [f] strain) and the propensity to invest in such a way that the propensity to invest decreases when the uncertainty associated with the project is high; the propensity to invest under the same emotions increases when the uncertainty is low.

Figure 1 illustrates our proposed model graphically:

Insert Figure 1 about here

\section{Research Method}

\section{Research technique}

We used a metric conjoint experiment to collect data on 101 entrepreneurs’ 3,232 decisions to persist with an investment. In conjoint experiments, individuals judge a number of hypothetical decision profiles. These profiles are based on a number of decision attributes, which are described by different levels (e.g., high and low) and represent the independent research variables (the decision represents the dependent variable). Conjoint studies have been applied widely in the fields of marketing, psychology, and strategic management (Green 
et al., 2001), and also in the study of entrepreneurial displays and decision making (e.g., DeTienne et al., 2008; Author, ref.) and investment decisions (e.g., Shepherd and Zacharakis, 1997). Moreover, conjoint analysis is considered a powerful tool in entrepreneurship research (Busenitz et al., 2003; Lohrke et al., 2010; Shepherd, 2011). Increasingly studies in the entrepreneurship domain are now performed using this technique (Lohrke et al., 2003), ranging from the investigation of research trends among entrepreneurship faculty (McMullen and Shepherd, 2006) to corporate entrepreneurship (Zampetakis and Moustakis, 2007), and to family firms (Shepherd and Zacharakis, 2000).

As compared to post-hoc methods such as questionnaires, interviews or surveys, the advantage of conjoint studies is that individuals' assessments are not biased due to their mistaken or missing introspection (Shepherd and Zacharakis, 1997) because this technique is specifically designed to capture participants' 'theories in use' at the moment of making a decision (Busenitz et al., 2003; Lohrke et al., 2010). Moreover, metric conjoint analysis allows researchers to analyze interaction relationships between variables (Priem and Harrison, 1994) as we postulate them in Hypotheses 3 and 4. Another important feature of conjoint analysis is its high predictive power as far as the real choice behavior is concerned (Green and Srinivasan, 1990).

Potential limitations of conjoint experiments relate to their face (or ecological) validity. For example, some have stated that participants may only take the attributes described in the scenarios as relevant for their assessments because those are part of the experimental task, and that the experimental design may be too abstract for individuals to perceive them as real-world situations (Shepherd and Zacharakis, 1997). The abstract nature of the scenarios may also result in lack of motivation in participants so that they withhold the cognitive efforts necessary to render their true judgments, and this in turn may question the reliability of data (Smith and Walker, 1993). 
To counteract these limitations, we followed the recommendations of Karren and Barringer (2002) and a) included only emotions where strong theoretical argumentation suggests that they impact entrepreneurs' persistence decisions, and b) asked individuals to self-report the importance of the described emotions for their decisions on a Likert-type scale from 1 (not important) to 7 (very important). Average responses were as follows: selfconfidence 6.1, hope 5.7, challenge 4.9, frustration 3.7, embarrassment 2.6, strain 3.7. In addition, we conducted a pilot study with a group of 15 entrepreneurs/owner-managers who helped us to improve our scenarios and also to confirm that our six emotions were relevant emotions during decision making. Thus we can state that all emotions have some selfreported importance for entrepreneurs' persistence decisions, and the study demonstrates high face validity, since all the emotions used as attributes in the conjoint analysis have been empirically validated. This manipulation is supported by the views of Hayton and Cholakova (2012) who posit that experimental manipulation of affect (emotions being recognized as affective states) among entrepreneurs can be particularly beneficial, since entrepreneurs might be more aware of their own affective states than others.

The face validity of conjoint experiments was extensively studied and verified in the early days of the methodology (Hammond and Adelman, 1976), this being a prerequisite for their extensive use across disciplines over the last 30 years (Green et al., 2001). Finally, the face validity of our experiment was supported by positive comments from the entrepreneurs after the experiment, such as: "I wish I knew how emotions affect me;" "My sales people would benefit from doing this;" “Are there ever any decisions that are emotion-free?” "Yes, there is often a mix of emotions when I make my decisions.”

\section{Sample description and data collection}

Our sample frame was entrepreneurs from firms located in Southern Sweden in a region considered an entrepreneurial district (Wigren, 2003). We compiled a list of 284 
companies from an official business register of manufacturing companies (except for agriculture and mining). We arranged this list in random order and started to call one firm after another until we reached a sample of 85 firms which agreed to participate in our study. In order to achieve this, we had to call 168 companies. In concentrating on one locality and on one industry we were able to eliminate as much unwanted heterogeneity of the sample as possible; thus our relatively homogeneous sample gave us the possibility to decrease variance and rule out alternative explanations unrelated to the theory in use (Davidsson, 2007).

We scheduled personal meetings with the entrepreneurs from these firms, however three meetings were cancelled. Thus, our final sample of entrepreneurs was from 82 firms, representing a response rate of 49 percent (compared with, e.g., the response rate of 24 percent in Choi and Shepherd, 2004); subsequent comparison of the final sample with the population did not reveal any non-response bias. Since 17 of these companies were managed by two or more owners, our final sample consisted of 101 entrepreneurs who participated in our study. The company visits were made by the authors between March and November 2007.

The sample size is fully comparable with other studies in entrepreneurship where conjoint analysis was used. According to Lohrke et al. (2010), in 16 studies performed between 1999 and 2008, the number of participants involved would range from 31 to 114 (with the exceptional case of 300 alumni from an Australian university in Douglas and Shepherd, 2002). As far as the number of firms is concerned, our study is again fully comparable with similar conjoint-based studies such as those by Shepherd (1999; 66 VCs in 47 firms), by Franke et al. (2008; 51 VCs from 26 firms), or by Author (2008; 91 employees from 31 firms).

The youngest of the participants was 31 years old and the eldest was 70 years old, mean age being 50.1 years. Eight percent were female, 44 percent had senior high school 
education, and 50 percent held a college or university degree. The most prominent areas of education were engineering (63 percent) and business administration (32 percent). On average, participants had held their current management positions for 11.4 years $(\mathrm{SD}=9.6)$ and 73 percent of the participants were CEOs. Their firms were on average 45.4 years old $(S D=28.2)$ and had 44 employees ( $S D=46)$. Since the entrepreneurs in this study include owner-managers, it is not surprising that the average age is high.

\section{Research instrument, description of the decision situation, and variables}

At the meetings, participants were informed about the purpose of the study and given more detailed instructions on the experimental task. Participants were told to assume that they were acting under current economic conditions in Sweden in general (i.e., in times of prosperity in 2007) and in their own company’s environment in particular and to consider all other factors potentially influencing their decisions as constant across all profiles. Subsequently, they were provided with a general description of the decision situation. They were asked to imagine a situation in which their company had 'has made a major investment (about two percent of the annual turnover) in a new project. As it turns out there is a need to contribute at least 15 percent of the invested sum'; this description indicates that (a) the project has been on-going for some time and sunk costs have occurred, and (b) that it will fail if the investment is not substantially increased. Thus, it describes a typical situation where decision-makers may persist with their commitment to a failing course of action (e.g., Garland, 1990). Participants were then given a more detailed description of the decision attributes and their levels (see below), followed by the decision profiles which were presented as a list of emotions and perceived outcome uncertainty associated with the project. The reference to persistence vs. withdrawal was to be made to the decision outcome in relation to the investment. Likewise, the reference to a 'failing investment' should refer to the current status, not the final outcome. They were asked to read the scenario and to position themselves 
in terms of the feeling of the emotion which they would ascribe themselves. It is possible for experienced entrepreneurs to relate to situations they have experienced before since emotions, once experienced, become part of a cognitive schema and may be retrieved on cue, such as in suggested scenarios (cf. Glaser, 1984).The researcher checked that all profiles were completed before ending the experiment.

The dependent variable of our study was the entrepreneur's propensity to allocate further resources to the described investment. A similar dependent variable analyzing the allocation of resources has previously been used in experimental studies on escalating commitment and persistence in underperforming investments (Sabherwal et al., 2003). We asked entrepreneurs to assess their willingness to allocate further resources to the investment on a seven-point Likert-type scale anchored by the end points 'completely willing to cut off the investment' and 'completely willing to continue the investment'.

The independent variables in our experiment were described by seven attributes, each of which comprised two levels. These attributes were split among six intended to describe the experienced emotions of the entrepreneur (self-confidence, hope, challenge, frustration, embarrassment, strain), one describing the uncertainty of project outcomes. In the scenarios, experience of emotions was described as either strong or weak, whereas uncertainty was described as either high or low, all in line with their definitions. To specify the level of independent variables (conjoint attributes) as high and low is a common technique in conjoint analysis, one which is often utilized in entrepreneurship research (cf. Green and Srinivasan, 1990; Lohrke et al., 2010; McMullen and Shepherd, 2006).

Self-confidence was described as 'The project makes me feel certain that it will turn out well and that I will have the ability to manage it' (cf. Barbalet, 1996). Hope was described as 'The project makes me feel that the goals will finally be met' (Henry, 2004). Challenge was described as 'The project makes me feel energized and it offers future 
opportunities for success, rewards, and personal growth’ (Lazarus, 1991b). Frustration was described as 'The project makes me feel upset and annoyed because something is interrupting the progress of the investment' (cf. Fox and Spector, 1999), indicating that obstacles will continue to occur during the future development path of the project in the case of persistence. Embarrassment was described as 'The project makes me feel that I will likely "lose face”" (cf. Goffman, 1956). Strain was described as 'The project makes me feel worried, nervous, exhausted, depressed and/or sleep badly because of its high demands’ (cf. Karasek, 1979), implying that demands and experienced levels of strain will continue to be high if the investment is continued. Finally, high uncertainty was described as 'Projections are contradictory and hard to interpret and the opinions in the management group are divided. You do not really know what the possible outcomes of the investment are', whereas low uncertainty was described as 'Projections are consistent and simple to interpret and the opinions in the management group are unanimous. You know what the possible outcomes of the investment are'. These descriptions are in line with the classification of entrepreneurial opportunities by level of uncertainty (Sarasvathy et al., 2003), ranging from ultimate uncertainty (cf. Knight, 1921; outcomes are unknowable) to low uncertainty (cf. Knight, outcome, supply and demand are known and can be calculated).

\section{Experimental design}

Since each scenario in our experiment includes seven attributes with two levels each, $2^{7}=128$ attribute combinations are possible. The evaluation of 128 scenarios would be a timeconsuming task for practitioners and can lead to informational overload, thus decreasing motivation to reveal participants' true preferences (Green and Srinivasan, 1990; Lohrke et al., 2010). To counteract these negative effects, and consistent with most conjoint studies, we used an orthogonal factorial design (Hahn and Shapiro, 1966; Sichtmann et al., 2010) to reduce the number of attribute combinations. This resulted in 16 different profiles. The 
orthogonal design ensured that the correlations of attributes were zero and multicollinearity was eliminated (Huber, 1987); we thus omit a correlation table. Our fractional factorial design confounded main effects and all two-way interactions of most interest (involving investment uncertainty) with other two-way and higher order interactions which made it unlikely that the latter would bias our results (Louviere, 1988).

We followed Karren and Barringer (2002) and tested for reliability of answers by replicating profiles and performing test-retest checks. Full replication of all 16 attribute combinations resulted in 32 profiles. Since the order of profiles and attributes may affect the results of conjoint experiments, we randomly assigned the 32 profiles as well as the attributes in two ways each, which yielded four versions of our experiment. These were then randomly distributed among participants. Consistent with other studies (Orme et al., 1997), we found no significant difference across versions and conclude that order effects had little impact on our results.

Finally, we included a 'practice' profile as a first evaluation task in order to make participants familiar with the decision situation (Shepherd and Zacharakis, 1997). This profile was excluded from the statistical analysis. Our final experimental design thus consisted of 33 profiles.

\section{Results}

Our statistical analysis draws on 32 decisions from 101 individuals, thus yielding a total of 3,232 data points. Calculation of Pearson correlations between tests and retest revealed that 79 percent of participants answered reliably $(p<0.05)$ and that the mean testretest correlation was 0.63 , which is consistent with other published studies (Choi and Shepherd, 2005). Further 82 percent of individual decision models were statistically significant with a mean $R^{2}$ of 0.75 , again similar to published work (Choi and Shepherd, 
2005). Thus, participating entrepreneurs consistently and reliably performed their experimental task.

It is important to note that the 3,232 data points of our study are not independent of each other since each set of 32 observations is nested within an individual entrepreneur. The appropriate statistical method to deal with nested data is Hierarchical Linear Modeling (HLM). In contrast to OLS regression techniques, HLM accommodates autocorrelation and the potential heteroskedasticity of data (Hofmann 1997). In experimental research, HLM separates variance at the decision level from variance at the individual level, and it is therefore the state-of-the-art statistical method to evaluate experimental data where more than one decision per individual is analyzed (e.g. Author ref.; Hitt et al., 2004). Table 1 presents our results.

Insert Table 1 about here

The results in Table 1 show that all anticipated emotions have a direct effect on the entrepreneurs' decision to persist with a seemingly failing project. That is, the entrepreneurs' willingness to continue their investment increases with stronger feelings of (a) selfconfidence, (b) hope, and (c) challenge, and decreases with stronger feelings of (d) frustration, (e) embarrassment and (f) strain. In terms of our hypotheses, H1a-c and H2d-e receive support.

However, our theory also suggested that the impact of entrepreneurs' emotions on their persistence would be moderated by the outcome uncertainty of the project. Thus, our model also included interactions between the emotion variables and investment uncertainty in explaining the decision to persist or not. Table 1 shows that five out of six interactions are 
significant $(p<0.05)$, that is, uncertainty moderates the influence of all emotions, except frustration, on the decision to persist. Thus, Hypothesis $4 \mathrm{~d}$ is not supported.

In order to gain a better understanding of the interactions between investment uncertainty and (a) self-confidence, (b) hope, (c) challenge, (e) embarrassment, and (f) strain in entrepreneurs' decision policies to persist with a failing investment, as illustrated in Figure 2, we plot these emotions against entrepreneurs' decision to persist with their investment (yaxis), and we draw separate lines for high and low investment uncertainty.

Insert Figure 2 about here

Figures 2A-C illustrate that, based on their decision policy, entrepreneurs are more prone to continue investment when they experience (a) self-confidence, (b) hope, and (c) challenge; the higher the level of uncertainty, the higher the positive influence of positive emotions on entrepreneurs' decisions to continue with their investments. Low uncertainty demonstrates a weaker relationship between emotions and propensity to invest. The nature of these significant interactions provides support for Hypotheses 3a, 3b, and 3c. Interestingly, Figure 2E illustrates that entrepreneurs are less prone to invest when they feel embarrassment, and that this relationship is reversed. In other words, the effect of embarrassment becomes more pronounced under low uncertainty compared to situations of high uncertainty, which is opposite to Hypothesis 4e. We will discuss this unexpected finding in the following section. Finally, Figure $2 \mathrm{~F}$ shows that entrepreneurs are less prone to invest when they experience strain, and that the propensity decreases under high uncertainty compared to situations of low uncertainty. This finding is in line with Hypothesis 4f. 


\section{Discussion, Implications and Future research}

This paper set out to hypothesize whether emotions matter to entrepreneurs in terms of investing in an underperforming project. In conclusion, it is possible to say that entrepreneurs when making reinvestment decisions are strongly affected by various emotions, some of which can lead to unwillingness to discontinue the investments. More precisely, entrepreneurs are more willing to continue their investment the more self-confidence, hope, and challenge they feel; conversely, the stronger the feelings of frustration, embarrassment and strain, the less inclined are they to continue with an investment. This may be an intuitive conclusion, and it confirms that emotions do indeed play a role for entrepreneurs in decision making where previous research has shown that people rely on emotions when they meet hindrances in decision-making situations (Damasio, 1994; Dane and Pratt, 2007; Foo, 2011), in risk decision situations (Podoynitsyna et al., 2012), and as an enhancer for taking decisions (Hayward et al., 2010; Podoynitsyna et al., 2012; Welpe et al., 2012), leading to higher creativity (Zhou and George, 2003).

\section{Emotions and uncertainty}

The present study deepens our understanding regarding interactions between emotions and uncertainty. Uncertainty seems to be a powerful moderator in the relationship between emotions and propensity to continue investment in a seemingly failing project; all emotions, except frustration, are affected by the level of uncertainty. Entrepreneurs who experience self-confidence, hope, and challenge become significantly more prone to continue investment under conditions of high uncertainty compared to low uncertainty levels. On the other hand, entrepreneurs who experience strain become increasingly willing to discontinue investment under high levels of uncertainty. Relatively little research is available on entrepreneurial reinvestment decisions toward failing investments. In an early study, McCarthy et al. (1993) found that entrepreneurs are more likely to expand their businesses as a reaction to negative 
feedback from the market when they are also founders of their firm, indicating that high levels of responsibility foster persistence. We can conclude that decision making under high levels of uncertainty is indeed different from decision making in more certain environments and tasks; this ought to be borne in mind, especially when providing normative advice for entrepreneurs.

Second, the contingency perspective of our study enabled us to extend the entrepreneurial emotions literature by identifying conditions under which emotions are more or less influential in the entrepreneurial decision-making process, and actually pose as cognitive elements. Current models usually assume that emotions are influential, but have not gone into detail concerning when their effect impacts the entrepreneurs' decisions more or less strongly. For instance, the aforementioned studies by Baron (2008) and Cardon et al. (2005) focus their attention on the direct effects of emotions on decision outcomes, or they use the entrepreneur's experienced emotions as a moderator impacting the effect of other decision cues on decision outcomes. For the particular case of emotions, our study suggests that emotional effects may themselves depend on the context of the decision - in our study the outcome uncertainty of a project. It is likely that other environmental factors may also influence the extent to which entrepreneurs rely on emotional cues vis $a$ vis other decision cues. For example, Baron (2008) suggests that positive emotions "may contribute to capacity for responding effectively in dynamic environments” (, p. 334), indicating that the impact of positive emotions on entrepreneurial decision making and success is contingent on environmental dynamism. As Author (ref.) suggests, the strong influence of positive emotions could be the way for decision-makers to cope with the situation's uncertainty, i.e., to function successfully under conditions which are typical for entrepreneurs.

Strain affects the propensity to invest to a high degree such that the propensity to invest decreases the higher the uncertainty. This is an important contribution to the literature 
on the consequences of stress. Professionals of this study seem to be able to respect this emotion in their decision-making process. It may be that seniority makes them capable of balancing linear (analytical) and nonlinear (emotional) thinking, relying on their intuition (cf. Groves et al., 2011).

Moreover, strong empirical evidence suggests that emotions are able to direct the decision-makers' attention to crucial pieces of information, facilitate learning from the decision-makers' own experience or the experience of others, as well as speed up memory processes (Miramatsu and Hanoch, 2005). Thus, emotions of hope, self-confidence, and challenge can trigger positive memories of successful investments in entrepreneurs who have already experienced such conditions. And, vice versa, emotions of strain and embarrassment can trigger negative memories of failed investments.

To understand the role of their emotions in investment decisions under different levels of uncertainty may help entrepreneurs to improve the quality of their decision making. Emotions can explain, partly, why entrepreneurs persist with some underperforming projects, but not others, since uncertainty seems to be a powerful moderating variable in the decisionmaking process. Further, different emotions play a different role which has practical implications. Practitioners who feel hope, challenge, and self-confidence demonstrate an increased propensity to invest when uncertainty is high, which, in our opinion, is a good sign in general. Without people taking such decisions, we would probably miss out on great opportunities. For these reasons, it can also be argued that it is not desirable to computerize all decision making.

\section{Embarrassment and escalation theory}

An important conclusion can be drawn from the correlation between the emotion of embarrassment and unwillingness to discontinue investment. We consider this behavior similar to the escalation of commitment and believe that our focus on emotions constitutes a 
contribution to the general literature on escalating commitment. While a few authors mention that escalation impacts the emotional state of decision-makers (Zeelenberg et al., 2002), only recently has the role of emotions in escalation situations been analyzed in more detail. In our study we can see that embarrassment would make entrepreneurs prone to discontinue investment; however, entrepreneurs become more prone to stop investing under low levels of uncertainty, and less prone to discontinue under high uncertainty levels. Our explanation is that a lower level of uncertainty implies that the outcome could be calculated with a certain precision; under such conditions we can presume that the decision-makers will apportion blame to themselves should the investment fail and, in order to avoid further embarrassment, they would rather discontinue investment. On the other hand, making decisions under high uncertainty implies a possibility of failure, which can be perceived as causing less embarrassment.

The propensity of entrepreneurs to discontinue investment when feeling embarrassed (especially under low levels of uncertainty) runs quite to the contrary to the arguments of self-justification theory (Ross and Staw, 1986), when decision-makers keep escalating their commitment to the failing course of action to avoid the embarrassment of admitting that the initial decision was wrong. Apparently, the entrepreneurial context and the strong sense of responsibility for one's company together prompt entrepreneurs to behave quite differently compared to decision-makers in large organizations where the escalation of commitment has predominantly been studied. If there is no one else to be accountable to, the entrepreneur does not have to justify a (dis)continuation. A parallel can be drawn with a study concerning businesses that are owner-managed; in the context in which the companies of this study operate, it has been established that the ownership logic (Author, ref.) does not allow for crusades which might jeopardize the firm's existence. This finding represents an interesting theoretical contribution. 


\section{Future research directions}

We may compare entrepreneurs' behavior in our study to the escalation of commitment, but we also show that such emotions are prior to, or at least simultaneous with, decision making. This calls for future research on the emotionalizing process in decision making. Further, as Wong et al. (2006) point out, entrepreneurs try to avoid negative emotions. This is also the tendency we see in this study, namely that strain and embarrassment lead entrepreneurs to discontinue investment in order to eliminate such negative feelings. Such a parallel also draws our attention to the complexity of emotions: do entrepreneurs, prior to or after, separate emotions from the decision to continue an underperforming project - and is it possible to separate them? Future studies can try to understand this relationship and how it affects entrepreneurs from a long-term perspective. Finally, all the emotions in this study are cognitive in nature, i.e., based on reflection and evaluation (Scherer, 2005) and the positive emotions are also action-oriented (Barbalet, 1996; Henry, 2004). A future research agenda is encouraged to take more aesthetic emotions (Lazarus, 1991b) into account.

A question that remains unanswered by the present study is whether making emotionbased decisions can be considered an adequate decision behavior. Simon (1982) pointed out that emotions represent an integral part of bounded rationality and play a significant role in choice behavior. Hammond et al. (1987) further developed this assumption, i.e., no decision is good or bad per se, but can be adequate or inadequate depending on the correspondence between the decision-making mode and the situation's cognitive properties. Thus, conditions of uncertainty would call for the use of heuristics in order for a decision to be adequate. However, the ability to match the decision-making mode with the situation's demand is a property of expert decision-makers (Hammond et al., 1987). Expert entrepreneurs possess this ability (Author, ref.); that is why we strongly believe that emotion-based decisions 
should not be regarded as inappropriate and inadequate. Entrepreneurs are notorious actiontakers (Sarasvathy, 2001); thus, if they possess expert decision-making skills, it is quite logical to assume that they are able to make adequate heuristic- or emotion-based decisions in accordance with the situation's cognitive nature. These arguments find support in Dew et al.'s (2009) study which investigated the role of heuristics, such as the affordable loss principle, in entrepreneurial action. According to the authors, the use of heuristics may lead to successful outcomes in strategic entrepreneurial decisions.

The scope of our research is limited by the number of potential decision cues that we could include in the decision scenarios. We focused on a limited number of emotions, and also on one specific moderating factor that impacts the effect of these emotions on the investment decision. Future research may use a design similar to that of our study to investigate other moderating factors that impact persistence, or researchers may draw on other methodological approaches such as policy capturing, which allow for the investigation of more decision cues in parallel, albeit at the expense of other methodological limitations (see Priem and Harrison, 1994). Future research can build on our study and investigate the impact of emotions on different steps of the entrepreneurial process, for example opportunity search and recognition, and entrepreneurial success.

Although the cultural impact of emotions has not been the main focus of this study, it should be noted here that emotions are culturally embedded and influenced by societal and organizational norms and values as well as by political and socio-economic differences (Moïsi, 2009). Given that this study took place in a Swedish context, the emotions here may be less valid in another cultural context.

Finally, a limitation of this study relates to the issue of defining emotions. Critics could argue that we label emotions as a mix of emotion, cognition, affect and mood (Gooty et al., 2009). Although we admit that clarity in constructs is important (cf. Suddaby, 2010), we 
decided to follow Cardon et al.'s (2012) definition of entrepreneurial emotions for this study.

Future studies may refine emotions into a more fine-grained construct and test them for possible differences in outcome.

\section{References}

Anderson, C.J. (2003), “The Psychology of Doing Nothing: Forms of Decision Avoidance Result from Reason and Emotion,” Psychological Bulletin, Vol.129 No. 1, pp. 139167.

Ashkanasy, N. M. (2003), “Emotions in organizations: A multilevel perspective”, in Dansereau, F and Yammarino, F.J. (Eds.), Research in multi-level issues, Elsevier Science, Oxford, pp. 9-54.

Averill, J.R., Catlin,G. and Chon, K.K. (1990), Rules of hope. Springer, New York

Barbalet, J.M. (1996), "Social Emotions: Confidence, Trust and Loyalty,” The International Journal of Sociology and Social Policy, Vol.16 No.9/10, pp. 75-96.

Baron, R.A. (1998), "Cognitive Mechanisms in Entrepreneurship: Why and When Entrepreneurs Think Differently than Other People,” Journal of Business Venturing, Vol.13, pp.275-294.

Baron, R.A. (2008),“The Role of Affect in the Entrepreneurial Process,” The Academy of Management Review, Vol.33 No.2, pp. 328-340.

Basch, J. and Fisher, C.D. (2000), "Affective events-emotions matrix: A classification of work events and associated emotions”, in Ashkanasy, N.M., Härtel, C.E. J. and Zerbe, W. (Eds.), Emotions in the Workplace: Research, Theory, and Practice, pp.36-48, Westport, CT: Quorum Books.

Breugst, N., Domurath, A., Patzelt, H. and Klaukien, A. (2012), "Perceptions of Entrepreneurial Passion and Employees' Commitment to Entrepreneurial Ventures”, Entrepreneurship Theory and Practice, Vol. 36 No. 1, pp. 171-192.

Brockner, J. (1992), "The Escalation of Commitment to a Failing Course of Action: Toward Theoretical Progress,” Academy of Management Review, Vol. 17 No. 1, pp. 39-61.

Busenitz, L, and J. Barney (1997), "Differences Between Entrepreneurs and Managers in Large Organisations: Biases and Heuristics in Strategic Decision-Making,” Journal of Business Venturing, Vol.12, pp. 9-30.

Busenitz, L.W., Page West III, G., Shepherd, D., Nelson, T., Chandler, G.N. and Zacharakis, A. (2003), "Entrepreneurship research in emergence: Past trends and future directions", Journal of Management, Vol. 29 No. 3, pp. 285-308

Cardon, M.S, C. Zietsma, P. Saparito, B.P. Matherne, and C. Davis (2005), “A Tale of Passion: New Insights into Entrepreneurship from a Parenthood Metaphor,” Journal of Business Venturing, Vol. 20 No.1, pp. 23-45.

Cardon, M.S., Foo, M-D, Shepherd, D. and J. Wiklund (2012), "Exploring the Heart: Entrepreneurial Emotion Is a Hot Topic”, Entrepreneurship, Theory and Practice, Vol. 36 No.1, pp. 1-10.

Choi, Y.R. and Shepherd, D.A. (2004), “Entrepreneurs' decisions to exploit opportunities”, Journal of Management, Vol. 30 No. 3, pp. 377-395.

Choi, Y.R, and D.A. Shepherd (2005), "Stakeholder Perceptions of Age and Other Dimensions of Newness”, Journal of Management, Vol.31 No.4, pp. 573-596. 
Cohen, M. (1993), “Three Paradigms for Viewing Decision Biases”, Decision-making in Action, Models and Methods, Klein, G.A., J. Orasanu, R. Calderwood, and C. Zsambok (eds), Norwood, NJ, Ablex Publishing Corporation.

Damasio, A.R. (1994), Descartes’ Error: Emotion, Reason, and the Human Brain. New York, Harper Collins Publishers.

Dane, E. and Pratt, M.G. (2007),“Exploring Intuition and Its Role in Managerial DecisionMaking”, Academy of Management Review, Vol. 32 No.1, pp. 33-54.

Davidsson, P. (2007), Dealing With Heterogeneity in Entrepreneurship Research, in, 4th AGSE International Entrepreneurship Research Exchange 2007, 6 - 9 February, Brisbane, Australia.

Darwin,C. (1872/1965), The Expression of the Emotions in Man and Animals. Chicago, University of Chicago Press

Dequech, D. (2000), “Confidence and Action: A Comment on Barbalet,” Journal of SocioEconomics, Vol. 29, pp. 503-515.

DeTienne, D.R., D.A. Shepherd, and J.O. De Castro (2008),“The Fallacy of “Only the Strong Survive":The Effects of Extrinsic Motivation on the Persistence Decisions for Underperforming Firms,” Journal of Business Venturing, Vol. 23 No.5, pp.528-546.

Dew, N., S. Sarasvathy, S. Read, and R.Wiltbank (2009), “Affordable Loss: Behavioral Economics Aspects of the Plunge Decision,” Strategic Entrepreneurship Journal, Vol.3, pp.105-126.

Douglas, E. J. and Shepherd, D. A. (2002), "Self-employment as a Career Choice: Attitudes, Entrepreneurial Intentions and Utility Maximisation”, Entrepreneurship Theory and Practice, Vol, 26 No. 3, pp. 81-90

Ekman, P. (1992), “Are there basic emotions?”, Psychological Review, Vol.99 No.3, pp. 550553.

Foo, M-D. (2011), "Emotions and Entrepreneurial Opportunity Evaluation”, Entrepreneurship Theory and Practice, Vol. 35 No. 2, pp. 375-393.

Fox, S., and P.E. Spector (1999), “A Model of Work Frustration-Aggression,” Journal of Organizational Behavior, Vol. 20, 915-931.

Franke, N., Gruber, M., Harhoff, D. and Henkel, J. (2008), "Venture capitalists‘ evaluation of start-up teams: trade-offs, knock-out criteria, and the impact of VC experience”, Entrepreneurship Theory and Practice, Vol. 32 No. 3, pp. 459-483.

Garland, H. (1990), "Throwing Good Money After Bad: The Effect of Sunk Costs on the Decision to Escalate Commitment to an Ongoing Project”, Journal of Applied Psychology, Vol.75 No.6, pp. 728-732.

Gifford, S. (1997), “Limited Attention and the Role of the Venture Capitalist”, Journal of Business Venturing, Vol.12, pp. 459-482.

Gimeno, J, T.B. Folta, A.C. Cooper, and Y. Woo (1997), "Survival of the Fittest? Entrepreneurial Human Capital and the Persistence of Underperforming Firms," Administrative Science Quarterly, Vol. 42, pp.750-783.

Glaser, R. (1984), “Education and Thinking: The Role of Knowledge”, American Psychologist, Vol.39 No. 2, pp.93-104.

Goffman, E. (1956), "Embarrassment and Social Organization,” American Journal of Sociology, Vol. 62, pp.264-274.

Gooty, J., Gavin, M. and Ashkanasy, N.M. (2009), "Emotions research in OB: The challenges that lie ahead”, Journal of Organizational Behavior, Vol. 30, pp. 833-838.

Green, P., A. Krieger, and Y. Wind (2001), "Thirty Years of Conjoint Analysis: Reflections and Prospects”, Interfaces, Vol. 31 No.3, pp. 56-73.

Green, P.E. and Srinivasan, V. (1990), "Conjoint analysis in marketing: New developments with implications for research and practice”, Journal of Marketing, October, pp. 3-19 
Groves, K, Vance, C. and Choi, D. (2011), “Examining Entrepreneurial Cognition: An Occupational Analysis of Balanced Linear and Nonlinear Thinking and Entrepreneurship Success”, Journal of Small Business Management, Vol. 49 No. 3, pp. 438-466.

Hahn, G., and S. Shapiro (1966), A Catalogue and Computer Program for the Design and Analysis of Orthogonal Symmetric and Asymmetric Fractional Factorial Designs. General Electric Corporation, Schenectady, NY.

Hammond, K.R., and L. Adelman (1976), “Science, Values, and Human Judgment,” Science, Vol.194 No.4263, pp.389-397.

Hammond, K.R., R.M. Hamm, J.Grassia, and T. Pearson (1987), "Direct Comparison of the Efficacy of Intuitive and Analytical Cognition in Expert Judgment”, IEEE Transactions on Systems, Man, and Cybernetics, Vol.17 No. 5, pp.753-770.

Hayton, J.C. and Cholakova, M. (2012), “The Role of Affect in the Creation and Intentional Pursuit of Entrepreneurial Ideas”, Entrepreneurship Theory and Practice, Vol. 36 No. 1, pp. 41-67.

Hayward, M.L.A., Forster, W.R. Sarasvathy, S.D. and Fredrickson, B.L. (2010), "Beyond hubris: How highly confident entrepreneurs rebound to venture again”, Journal of Business Venturing, Vol. 25, No. 6, pp.569-578.

Henry, P. (2004), “Hope, Hopelessness, and Coping: A Framework for Class-Distinctive Cognitive Capital”, Psychology \& Marketing, Vol. 21 No. 5, pp. 375-403.

Herbert, R.F., and A.N. Link (1988), The Entrepreneur, Mainstream Views and Radical Critiques, Praeger, New York.

Hitt, M.A., D. Ahlstrom, M.T. Dacin, E. Levitas, and L. Svobodina (2004), "The Institutional Effects on Strategic Alliance Partner Selection in Transition Economies: China vs. Russia”, Organization Science, Vol.15 No.2, pp.173-185.

Hofmann, D.A. (1997), "An Overview of the Logic and the Rationale of Hierarchical Linear Models”, Journal of Management, Vol. 23, pp.783-804.

Huber, J. (1987), “Conjoint Analysis: How We Got Here and Where We Are,” Sawtooth Software Research Paper Series, Sequim, WA.

Hutri, M. and M. Lindeman (2002), "The Role of Stress and Negative Emotions in an Occupational Crisis”, Journal of Career Development, Vol. 29 No. 1, pp. 19-36.

Isen, A.M., K.A. Daubman, and G.P.Nowicki (1987), "Positive Affect Facilitates Creative Problem Solving”, Journal of Personality and Social Psychology, Vol. 52, pp. 11221131.

Kahneman, D., and A. Tversky (1973), “On the Psychology of Prediction”, Psychological Review, Vol. 80 No.4, pp. 237-251.

Kahneman, D., A. Treisman, and B. Gibbs (1992), “The Reviewing of Object Files: ObjectSpecific Integration of Information”, Cognitive Psychology,Vol. 24, No.2, pp. 175219.

Karakaya, F. (2000), “Market Exit and Barriers to Exit: Theory and Practice,” Psychology \& Marketing, Vol. 17 No. 8, pp. 651-668.

Karasek, R.A. (1979), “Job Demands, Job Decision Latitude, and Mental Strain: Implications for Job Redesign,” Administrative Science Quarterly, Vol. 24 No. 2, pp. 285-308.

Karlsson, N., T. Gärling, and N. Bonini (2005), "Escalation of Commitment with Transparent Future Outcomes”, Experimental Psychology, Vol. 52 No.1, pp. 1-7.

Karren, R.J., and M.W. Barringer (2002), “A Review and Analysis of the Policy-Capturing Methodology in Organizational Research: Guidelines for Research and Practice”, Organizational Research Methods, Vol. 5 No. 4, pp. 337-361.

Knight, F.H. (1921), Risk, Uncertainty and Profit, Houghton Mifflin, New York. 
Lazarus, R.S. (1984), “On the Primacy of Cognition”, American Psychologist, Vol. 39 No. 2, pp. 124-129.

Lazarus, R.S. (1991a), “Cognition and Motivation in Emotion,” American Psychologist 46 (4), 352-367.

Lazarus, R.S. (1991b), "Progress on a Cognitive-Motivational-Relational Theory of Emotion”, American Psychologist, Vol. 46 No. 8, pp. 819-834.

Lazarus, R. S., and Cohen-Charash, Y. (2001), “Discrete emotions in organizational life”. In Payne, R. and \& Cooper, C. (Eds.), Emotions at Work: Theory, Research and Applications for Management, John Wiley, Chichester, pp. 45-84.

Levinthal, D.A. (1991), "Random Walks and Organizational Mortality,” Administrative Science Quarterly, Vol. 36 No. 3, pp. 397-420.

Loewenstein, G.F., E.U. Weber, C.K. Hsee, and N. Welch (2001), “Risk as Feelings”, Psychological Bulletin, Vol.127 No. 2, pp. 267-286.

Lohrke, F.T., Holloway, B.B. and Woolley, T.W. (2010), “Conjoint analysis in entrepreneurship research. A review and research agenda”, Organizational Research Method, Vol, 13 No. 1, pp. 16-30

Louviere, J. (1988), Analyzing decision-making, Metric Conjoint Analysis. Sage Publications: Newbury Park, CA.

Lucey, B.M. and Dowling, M. (2005), “The role of feelings in investor decision-making”, Journal of Economic Surveys, Vol. 19 No. 2, pp. 211-237.

McMullen, J. and Shepherd, D. (2006), "Encouraging consensus-challenging research in universities”, Journal of Management Studies, 43, pp. 1643-1669.

Markman, G.D., Balkin, D.B. and Baron, R.A. (2002), "Inventors and New Venture Formation: The Effects of general self-efficacy and regretful thinking”, Entrepreneurship Theory and Practice, Vol. 27 No. 2, pp. 149-165.

McCarthy, A.M., F.D. Schoorman, and A.C. Cooper (1993), "Reinvestment Decisions by Entrepreneurs: Rational Decision-Making or Escalation of Commitment?”, Journal of Business Venturing, Vol. 8 No.1, pp. 9-24.

McColl-Kennedy, J.R., and R.D. Anderson (2002), "Impact of Leadership Style and Emotions on Subordinate Performance”, The Leadership Quarterly, Vol. 13 No. 5, pp. 545-559.

McGrath, R.G. (1999), "Falling Forward: Real Options Reasoning and Entrepreneurial Failure", Academy of Management Review, Vol. 24 No. 1, pp.13-30.

McMullen, J.S., and D.A. Shepherd (2006), "Entrepreneurial Action and the Role of Uncertainty in the Theory of the Entrepreneur”, Academy of Management Review, Vol. 31 No. 1, pp. 132-152.

Michl, T., I.M. Welpe, M. Spörrle, and A. Picot (2009), “The Role of Emotions and Cognitions in Entrepreneurial Decision-Making”, in Understanding the Entrepreneurial Mind, Opening the Black Box, A.L. Carsrud, and M. Brännback (eds.) Springer

Miller, R. S., \& Leary, M. R. (1992), "Social sources and interactive functions of emotion: The case of embarrassment”, in Clark, M. (Ed.), Review of'personality and social psychology, Vol. 14, pp. 202-221, Sage, Newbury Park, CA.

Miramatsu, R., and Y. Hanoch (2005), "Emotions as a Mechanism for Boundedly Rational Agents: The Fast and Frugal Way”, Journal of Economic Psychology, Vol. 26, pp. 201-221.

Mitchell, R., L. Busenitz, T. Lant, P. McDougall, E. Morse, and B. Smith (2002), “Toward a Theory of Entrepreneurial Cognition: Rethinking the People Side of Entrepreneurship Research”, Entrepreneurship Theory and Practice, Vol. 27 No. 2, pp. 93-104. 
Moîsi, D. (2009), The Geo Politics of Emotions: how cultures of fear, humiliation, and hope are reshaping the world. London: Bodley Books.

Northcraft, G.B., and M.A. Neale (1986), "Opportunity Costs and the Framing of Resource Allocation Decisions”, Organisational Behavior and Human Decision Processes, Vol. 37, pp. 348-356.

Orme, B.K., Alpert, M.I., Christensen, E. (1997), Assessing the Validity of Conjoint Analysis. Sequim, WA: Sawtooth Software Research Paper Series.

Parkinson, V., Totterdell, P., Briner, R.B. and Reynold, S. (1996), "Changing moods”, The Psychology of Mood and Mood \& Mood Regulation. London and New York, Longman

Pierce, J.L., D.G. Gardener, L.L. Cummings, and R.B. Dunham (1989), “Organization-Based Self-Esteem: Construct Definition, Management and Validation”, Academy of Management Journal, Vol. 32 No. 3, pp. 622-648.

Podoynitsyna, K., Vand der Bij, H. and Song, M. (2012), “The Role of Mixed Emotions in the Risk Perception of Novice and Serial Entrepreneurs”, Entrepreneurship Theory and Practice, Vol. 36 No. 1, pp. 115-40.

Priem, R.L., and D.A. Harrison (1994), "Exploring Strategic Judgment: Methods for Testing the Assumptions of Prescriptive Contingency Theories”, Strategic Management Journal, Vol. 15 No. 4, pp. 311-324.

Rafaeli, A., and R.I. Sutton (1987), "Expression of Emotion as Part of the Work Role”, Academy of Management Review, Vol. 12, pp. 23-37.

Ross, J., and B.M. Staw (1986), “Expo 86: An Escalation Prototype”, Administrative Science Quarterly, Vol. 31 No. 2, pp. 274-297.

Sabherwal, R., M.K. Sein, and G.M. Marakas (2003), "Escalating Commitment to Information System Projects: Findings from Two Simulated Experiments”, Information \& Management, Vol. 40 No. 8, pp. 781-798.

Sarasvathy, S. (2001), "Causation and Effectuation: Towards a Theoretical Shift from Economic Inevitability to Entrepreneurial Contingency”, Academy of Management Review, Vol. 26 No. 2, pp. 243-263.

Sarasvathy, S., Dew, N., Velamuri, S.R. and Venkataraman, S. (2003), "Three views of entrepreneurial opportunity”, in Acs Z.J. and Audretsch, D.B. (eds), Handbook of Entrepreneurship Research. Kluwer Academic Publishers.

Shaver, P., J. Schwartz, D.Kirson, and C. O’Connor (1987), “Emotion knowledge. Further Exploration of a Prototype Approach”, Journal of Personality and Social Psychology, Vol. 52, pp. 1061-86.

Scherer, K.R. (2005), “What are emotions? Can they be measured?” Social Science Information, Vol. 44 No. 4, pp. 695-729.

Shepherd, D. A., and Zacharakis. A. (1997). "Conjoint analysis: A window of opportunity for entrepreneurship research," Advances in entrepreneurship, firm emergence and growth Vol. 3, pp. 203-248.

Shepherd, D. (1999), "Venture capitalists' assessment of new venture survival”, Management Science, 45, pp. 621-632.

Shepherd, D.A. (2011), "Multilevel entrepreneurship research: Opportunities for studying entrepreneurial decision-making”, Journal of Management, Vol. 37 No. 2, pp. 412 420

Shepherd, D.A. and Zacharakis, A. (2000), "Structuring family business succession: An analysis of the future leaders' decision making”, Entrepreneurship Theory and Practice, Vol. 24, No. 4, pp. 25-39. 
Sichtmann, C., Wilken, R. and Diamantopoulos, A. (2011), "Estimating willingness-to-pay with choice-based conjoint analysis - can consumer characteristics explain variation in accuracy?” British Journal of Management, Vol. 22, pp. 628-645.

Simon, H. A. (1982), Models of bounded rationality, MIT Press, Cambridge, MA.

Skinner, N., and Brewer, N. (2002), "Dynamics of threat and challenge appraisals prior to stressful achievement events”, Journal of Personality and Social Psychology, Vol. 83 No. 3, pp. 678-692.

Smith, V. and Walker, J. (1993), "Monetary rewards and decision costs in experimental economics”, Economic Inquiry, Vol. 31, pp. 245-261.

Snyder, C. R. (1995), “Conceptualizing, measuring, and nurturing hope”, Journal of Counseling and Development, Vol. 73, No. 3, pp. 355-360.

Snyder, R.C. (2002), “Hope Theory: Rainbows in the Mind”, Psychological Inquiry, Vol. 13 No. 4, pp. 249-275

Staw, B. M. (1981), “The escalation of commitment to a course of action”, Academy of management Review, Vol. 6 No. 4, pp. 577-587.

Tversky, A, and D. Kahneman (1974), “Judgment under Uncertainty: Heuristics and Biases,” Science,Vol. 27 No.185, pp. 1124-1131.

Ucbasaran, D., G. Alsos, P. Westhead, and M.Wright (2008), "Habitual Entrepreneurs”, Foundations and Trends in Entrepreneurship, Vol. 4, pp.1-93.

Welpe, I., M. Spörrle, D. Grichnik, T. Michl, and D.B. Audretsch (2012), “Emotions and Opportunities: The Interplay of Opportunity Evaluation, Fear, Joy, and Anger as Antecedent of Entrepreneurial Exploitation”, Entrepreneurship Theory and Practice, Vol. 36 No. 1, pp. 69-96.

Van Kleef, G. A., De Dreu, C. KW. and Manstead A. SR. (2010), "An interpersonal approach to emotion in social decision making: The emotions as social information model", Advances in experimental social psychology, Vol. 42, pp. 45-96.

Wigren, C. (2003), The Spirit of Gnosjö, The grand narrative and beyond. Dissertation, Jönköping University, Jönköping.

Wong, K.F.E., Yik, M and Kwong, J.Y.Y. (2006), "Understanding the Emotional Aspects of Escalation of Commitment: The Role of Negative Effect, Journal of Applied Psychology, Vol. 91 No. 2, pp. 282-297.

Yukl, G. (2010), Leadership in Organizations, Pearson Education, New Jersey.

Zampetakis, L.A. and Moustakis, V. (2007), "Fostering corporate entrepreneurship through internal marketing. Implications for change in the public sector”, Internal Marketing, Vol. 10 No. 4, pp. 413-433.

Zeelenberg, M., Van den Bos, K., Van Dijk, E., \& Pieters, R. (2002), “The inaction effect in the psychology of regret”, Journal of Personality and Social Psychology, Vol. 82 No. 3 pp. 314-327.

Zhou, J. and George, J.M. (2003), "Awakening employee creativity: The role of leader emotional intelligence." The Leadership Quarterly, Vol. 14 No. 4, pp. 545-568 